Volume. 15, Nomor 1, Juní 2019

\title{
Pengaruh Implementasi Total Quality Management \\ Terhadap Kinerja Karyawan \\ (Studi Pada PT. PLN (Persero) Cabang Gorontalo)
}

\author{
Mahfiza \\ IAIN Sultan Amai Gorontalo \\ mahfiza001@gmail.com
}

\begin{abstract}
Abstrak
Tujuan yang ingin dicapai dalam penelitian ini adalah untuk mengetahui seberapa besar pengaruh Penerapan Total Quality Management (X) yang meliputi : Fokus pada Pelanggan (X1), Perbaikan proses berkesinambungan (X2) dan Keterlibatan dan Pemberdayaan Karyawan (X3) terhadap Kinerja Karyawan pada PT. PLN Cabang Gorontalo. Metode yang digunakan dalam penelitian ini adalah metode kuantitatif dengan pendekatan survey. maka yang menjadi sampel pada penelitian ini adalah seluruh karyawan yang terkait dengan penerapan TQM sebanyak 40 orang yang meliputi keseluruhan bagian pelayanan dan administrasi, didalamnya melingkupi Keuangan dan Akuntansi, bagian yang membidangi transaksi energy listrik, bagian jaringan dan bagian pembangkitan pada PT.PLN Cabang Gorontalo. Hasil Penelitian menunjukkan bahwa Penerapan Total Quality Management (X) yang meliputi : Fokus pada Pelanggan (X1), Perbaikan proses berkesinambungan (X2) dan Keterlibatan dan Pemberdayaan Karyawan (X3) secara simultan berpengaruh positif dan signifikan terhadap Kinerja Karyawan pada PT. PLN Cabang Gorontalo. Sebesar 67,4\%., dan selebihan 32,6\% dipengaruhi oleh variabel lain yang belum diteliti, misalnya kesatuan tujuan, kerjasama tim, obsesi yang tinggi terhadap kualitas, pendekatan ilmiah dalam pengambilan keputusan dan pemecahan masalah.
\end{abstract}

Kata Kunci : Total Quality Management, Kinerja Karyawan 


\section{Pendahuluan}

Di dalam melaksanakan aktivitasnya, suatu perusahaan membutuhkan faktorfaktor produksi yang saling berkaitan antara satu dengan yang lainnya,yaitu faktor-faktor sumber daya alami, teknologi, modal dan sumber daya manusia. Keempat faktor tersebut harus bekerja sama dan dikelola dengan baik agar perusahaan memperoleh hasil yang maksimal.

Oleh karena itu perusahaan harus meningkatkan kinerja para karyawannya. Salah satu cara untuk meningkatkan kinerja karyawan dapat ditempuh dengan menerapkan teknik Total Quality Management (TQM). TQM merupakan satu cara memperbaiki untuk meningkatkan proses bisnis secara terus menerus atau cara memperbaiki dan meningkatkan efektifitas dan efisiensi penggunaan sumber daya perusahaan untuk memenuhi kebutuhan pelanggan dan memuaskan pelanggan (Darsono dan Ari Purwanti, 2009). Dengan diterapkannya teknik Total Quality Management (TQM) baik perusahaan maupun karyawan diupayakan perbaikan berkesinambungan terhadap kemampuan manusia, proses dan lingkungan, sehingga perusahaan meningkatkan labanya (Fandy ,2005).

PLN sebagai Badan Usaha Milik Negara yang berbentuk Perusahaan Perseroan (Persero) telah berkomitmen meningkatkan kinerja ekselen menuju perusahaan yang berkelas dunia telah menginplementasikan model Total Quality Management(TQM) dalam bentuk Malcolm Balridge Criteria for Performance Excellence (MBCfPE). Dengan model program TQM yang diimplementasikan secara total di seluruh lini, dengan menggunakan assessment berdasarkan metode Baldridge, maka dapat diperkirakan akan terjadi akselerasi peningkatan kinerja yang massive terarah dan terukur secara bersamasama di semua unit korporasi dan anak perusahaan yang akan mempercepat PLN masuk dalam level perusahaan Emerging Industry menuju ke level Industry Leader dan meningkat menjadi World Class Company diwaktu datang .

Dalam memasuki usianya yang semakin matang, ditengah pesatnya kemajuan perusahaan, tidak luput dari tantangan yang masih menjadi kendala, hal ini juga di alami PLN unit Wilayah Sulawesi Utara, Tengah, dan Gorontalo, dalam dekade saat ini berbagai masalah masih sering terjadi yakni: Masalah kelangkaan pasokan listrik merupakan masalah penting yang harus dipecahkan oleh PLN Cabang Gorontalo dan 
pemerintah daerah serta masyarakat Gorontalo. Pemadaman bergilir yang rutin terjadi belakangan ini tentunya sangat merugikan masyarakat/pelanggan dan para investor yang telah ada ataupun hendak datang berinvestasi di Gorontalo, Pelayanan pelanggan baru yang sangat lamban sehingga harus menunggu berhari-hari bahkan berbulan-bulan sehingga muncul keresahan dan keluhan dikalangan masyarakat dan pelanggan yang membutuhkan pelayanan PLN.

Seperti yang diketahui bahwa pelanggan lebih senang akan kemudahan memperoleh informasi dan pelayanan karyawan yang cepat, ramah dan mudah, pentingnya pelayanan dan pelanggan bagi perusahaan terutama PT. PLN Cabang Gorontalo, serta untuk meningkatkan kualitas pelayanan dan kepuasan pelanggan.

\section{Kajian Pustaka}

\section{A. Total Quality Management}

Menurut ISO, TQM adalah pendekatan manajemen pada suatu organisasi, berfokus pada kualitas dan didasarkan atas partisipasi dari keseluruhan sumber daya manusia dan ditujukan pada kesuksesan jangkapanjang melalui kepuasan pelanggan dan memberikan manfaat pada anggota organisasi (sumber daya manusianya) dan masyarakat. Tujuan utama TQM adalah perbaikan mutu pelayanan secara terusmenerus.

Unsur-unsur yang terkandung dalam Total Quality Management (TQM) adalah :

\section{Fokus pada pelanggan.}

Misi utama dari sebuah institusi Total Quality Management (TQM) adalah memenuhi kebutuhan dan keinginan pelanggannya. Organisasi pendidikan yang unggul, menurut Peters dan Waterman dalam Sallis (2005:27) adalah organisasi yang dapat menjaga hubungan dengan pelanggannya dan memiliki obsesi terhadap mutu.

\section{Perbaikan yang Berkesiambungan}

Perbaikan yang berkesinambungan mempunyai arti umum dan arti khusus dalam Total Quality Management (TQM). Arti umumnya adalah usaha yang terus menerus untuk secara sederhana melakukan perbaikan dalam setiap organisasi. Arti yang lebih spesifik berfokus pada perbaikan yang berkesinambungan dalam mutu proses dalam pekerjaan yang diselesaikan. Ini berarti bahwa perbaikan yang berkesinambungan 
adalah suatu filosof manajemen yang mengarah pada tantangan dari produk atau perbaikan proses sebagai proses yang tidak pernah berakhir dan mencapai kemenagan yang kecil (Tunggal dalam Laksmi, 2005). Thompson dalam laksmi (2005), secara khusus perbaikan yang berkesinambungan akan melakukan perbaikan secara terus menerus dari mesin, material, utilitas tenaga kerja, dan metodemetodeproduksi melalui aplikasi dari usulan-usulan dan ide-ide anggota kelompok. Keberhasilan sistem perbaikan yang berkesinambungan harus memenuhi persyaratan manajemen sebagai berikut :

a. Perbaikan memerlukan periode belajar sebelum mereka memberikan manfaat dengan menetapkan target perbaikan. Walaupun perbaikan yang berkesinambungan berfokus pada perbaikan kecil yang diimplementasikan secara cepat, perbaikan yang kecilpun menyebabkan alokasi yang tidak benar, dan sebab itu mengakibatkan pengurangan output dalam jangka pendek.

b. Tenaga kerja dan manajemen harus saling mempercayai untuk menghasilkan arus ide yang bebas untuk mendorong usaha perbaikan yang berkesinambungan.

c. Suatu sistem penghargaan harus menigkatkan kerjasama antara departemen.

d. Perbaikan yang berkesinambungan sama dengan pelatihan berkesinambungan. pelatihan berkesinambungan terdiri atas dua tipe, yaitu : Pelatihan dalam metode pemecahan masalah, yang mengarahkan perbaikan, dan Pelatihan dalam posedur baru, yang diperlukan untuk mengoperasionalkan perbaikan diri.

e. Perbaikan yang berkesinambungan memerlukan sistem yang efisien, untuk menangani ide perbaikan dan mengadministrasikan proses penghargaan. Tanpa alat yang direncanakan dengan baik untuk mengumpulkan, menilai, mengimplementasikan, dan member penghargaan, usaha perbaikan yang berkesinambungan tidak akan berhasil (Tunggal dalam Laksmi,2005).

\section{Keterlibatan dan Pemberdayaan Karyawan}

Pemberdayaan dapat diartikan sebagai pelibatan karyawan yang benar-benar berarti (signifikan). Dengan demikian, pemberdayaan tidak hanya sekedar memberikan masukan, tetapi juga memperhatikan, mempertimbangkan, dan menindaklanjuti masukan tersebut apakah akan diterima atau tidak. Tanpa adanya pemberdayaan, pelibatan karyawan hanyalah merupakan alat manajemen yang tidak ada gunanya (Fandy Tjiptono dalam Laksmi, 2005). 
Lebih lanjut Fandy Tjiptono, mengemukakan bahwa pelibatan harus dibarengi dengan pemberdayaan karyawan. Usaha pemberdayaan karyawan dapat dimulai dengan :

a. Keinginan menejer dan penyedia untuk memberi tanggung jawab kepada karyawan

b. Melatih penyedia dan karyawan mengenai bagaimana cara untuk melakukan delegasi dan menerima tanggung jawab

c. Komunikasi dan umpan balik perlu diberikan oleh menejer dan penyedia kepada karyawan.

d. Penghargaan dan pengakuan sebagai hasil evaluasi perlu diberikan kepada karyawan sebagai tanda penghargaan terhadap kontribusi mereka kepada perusahaan.

\section{Penyebab Kegagalan Total Quality Management}

Secara umum penyebab kegagalan TQM disebabkan oleh:

1. Delegasi dan kepemimpinan yang tidak baik dari manajer senior

2. Proses penyebarluasan

3. Menggunakan pendekatan yang terbatas

4. Harapan yang terlalu berlebihan dan tidak realistis

Masih banyak kesalahan yang lain yang sering dilakukna berkaitan dengan program TQM dalam suatu perusahaan. Apabila suatu perusahaan benar- benar memahami konsep TQM sebelum mencoba menerapkannya, maka kesalahan- kesalahan tersebut dapat dihindari.

TQM dalam sebuah perusahaan bukanlah hal yang mudah untuk dilakukan dalam waktu tertentu saja. TQM juga harus dilaksanakan dengan sistem koordinasi kepada anggota karena peningkatan kualitas bukan saja tanggung jawab manajer semata, melainkan tanggung jawab bersama dan harus disesuaikan dengan keadaan perusahaan serta kebutuhan yang harus dijawab. J.Saragih, (2008; 31-33)

\section{B. Kinerja karyawan}

Menurut Henry Simamora dikutip dan diterjemahkan oleh Dina Nurhayati (2008: 7) "Kinerja karyawan adalah tingkat dimana para karyawan mencapai persyaratanpersyaratan pekerjaan”. Menurut Malayu S.P. Hasibuan (2006: 94) menjelaskan bahwa 
"Kinerja merupakan hasil kerja yang dicapai seseorang dalam melaksanakan tugas-tugas yang dibebankan kepadanya didasarkan atas kecakapan, pengalaman, kesungguhan serta waktu". Sedangkan menurut Suyadi Prawirosentono (2008: 2) "Kinerja atau dalam bahasa inggris adalah performance", yaitu: Hasil kerja yang dapat dicapai oleh seseorang atau sekelompok orang dalam organisasi, sesuai dengan wewenang dan tanggung jawab masing-masing dalam rangka upaya mencapai tujuan organisasi bersangkutan secara legal, tidak melanggar hokum dan sesuai dengan moral maupun etika. Dari beberapa pengertian diatas, dapat disimpulkan bahwa kinerja karyawan adalah kemampuan mencapai persyaratanpersyaratan pekerjaan, dimana suatu target kerja dapat diselesaikan pada waktu yang tepat atau tidak melampui batas waktu yang disediakan sehingga tujuannya akan sesuai dengan moral maupun etika perusahaan. Dengan demikian kinerja karyawan dapat memberikan kontribusi bagi perusahaan tersebut.

Menurut Alex Soemadji Nitisemito (2001: 109), terdapat berbagai faktor kinerja karyawan, antara lain:

1) Jumlah dan komposisi dari kompensasi yang diberikan.

2) Penempatan kerja yang tepat.

3) Pelatihan dan promosi.

4) Rasa aman di masa depan (dengan adanya pesangon dan sebagainya).

5) Hubungan dengan rekan kerja.

6) Hubungan dengan pemimpin.

\section{Kerangka Pemikiran}

Berdasarkan latar belakang dan kajian pustaka yang telah dikemukakan di atas, maka oleh penulis dikembangkan suatu pemikiran hubungan Total Quality Management dengan Kinerja Karyawan dengan bagan sebagai berikut: 


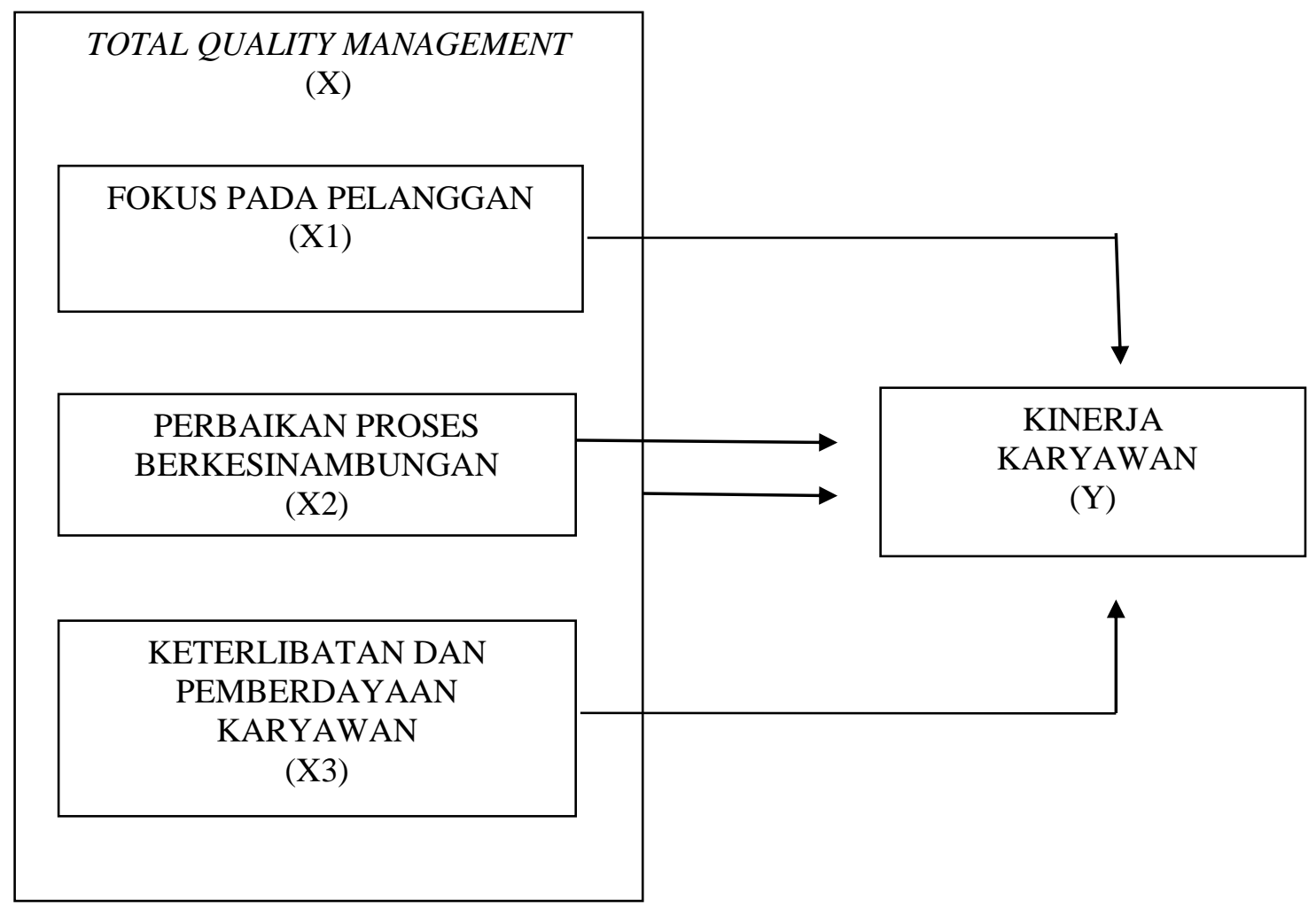

Gambar : Kerangka Pemikiran

\section{Pengujian Hipotesis}

Koefisien jalur dari variabel X1, X2 dan X3 serta variabel luar terhadap variabel Y dalam penelitian ini dapat digambarkan sebagai berikut
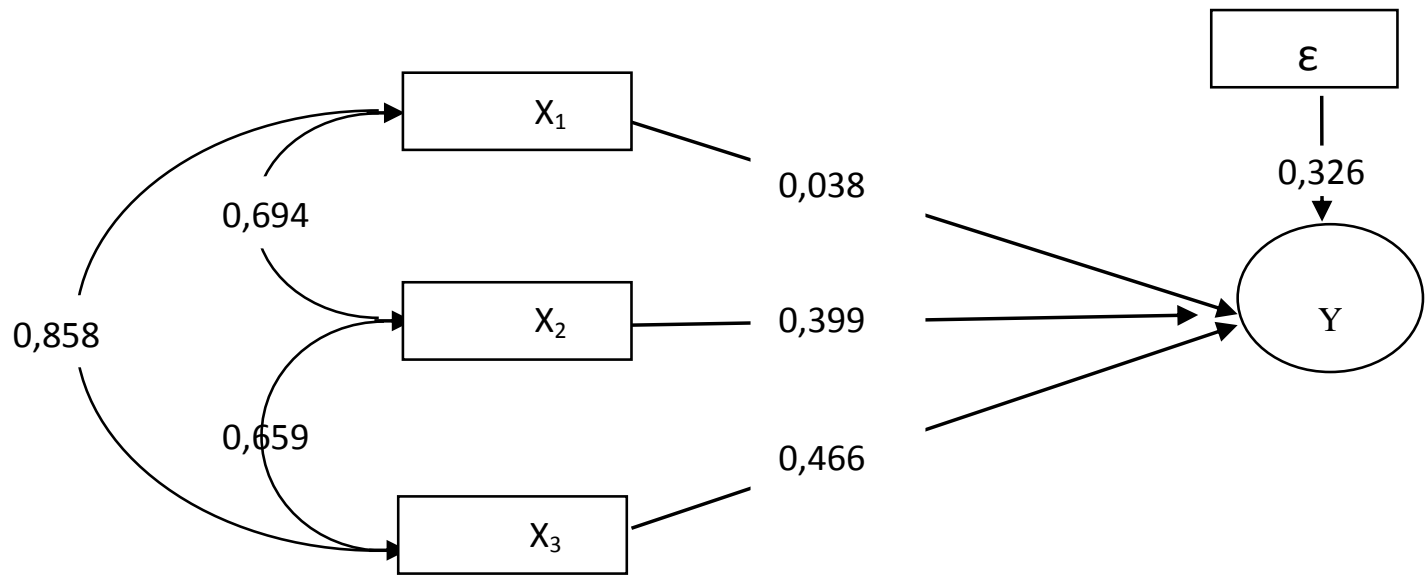

Gambar 4.1 Koefisien Jalur variabel X1,X2 dan variabel lain terhadap variabel Y 
Tabel 4.14 : Hasil Estimasi Pengujian Hipotesis dan Besarnya Pengaruh variabel X terhadap Y

\begin{tabular}{|l|l|l|l|l|l|}
\hline $\begin{array}{c}\text { Pengaruh } \\
\text { Variabel X } \\
\text { Terhadap Y }\end{array}$ & $\begin{array}{c}\text { Besarnya } \\
\text { Nilai } \\
\text { Pengaruh }\end{array}$ & $\begin{array}{c}\text { Nilai } \\
\text { Sig }\end{array}$ & $\begin{array}{c}\text { Crombact } \\
\text { Alpha }\end{array}$ & Hasil & Kesimpulan \\
\hline $\mathrm{X} 1, \mathrm{X} 2, \mathrm{X} 3 \rightarrow \mathrm{Y}$ & 0,674 & 0,000 & 0,05 & Signifikan & Diterima \\
\hline $\mathrm{X} 1 \rightarrow \mathrm{Y}$ & 0,038 & 0,848 & 0,05 & $\begin{array}{c}\text { Tidak } \\
\text { Signifikan }\end{array}$ & Ditolak \\
\hline $\mathrm{X} 2 \rightarrow \mathrm{Y}$ & 0,399 & 0,005 & 0,05 & Signifikan & Diterima \\
\hline $\mathrm{X} 3 \rightarrow \mathrm{Y}$ & 0,466 & 0,018 & 0,05 & Signifikan & Diterima \\
\hline
\end{tabular}

Sumber : Olahan data dengan SPSS 14

\section{Pembahasan Hasil Penelitian}

Berdasarkan hasil data statistik dan pengujian hipotesis yang telah dilakukan, maka dapat dijelaskan masing-masing hipotesis sebagai berikut :

\section{a. Penerapan Total Quality Management secara simultan berpengaruh positif dan signifikan terhadap Kinerja Karyawan pada PT. PLN Cabang Gorontalo.}

Besarnya pengaruh Total Quality Management berkonstribusi terhadap kinerja karyawan adalah sebesar 67,4\%, hal ini menandakan bahwa secara empirik dilapangan penerapan TQM yakni fokus pada pelanggan, perbaikan proses berkesinambungan, dan keterlibatan dan pemberdayaan karyawan sangat dibutuhkan. TQM merupakan system yang melakukan kegiatan perbaikan terus menerus, salah satunya terhadap karyawan. Penerapan TQM efektif apabila setiap karyawan memiliki pengetahuan dan pemahaman mengenai mutu serta dapat memahami harapan dan kebutuhan pelanggan. Adanya kepuasan pelanggan, perbaikan secara terus menerus serta keterlibatan dan pemberdayaan karyawan yang merupakan faktor dominan, dapat memberikan manfaat, salah satunya adalah reputasi perusahaan menjadi baik sehingga laba perusahaan yang diperoleh meningkat. Hal ini secara lansung maupun tidak lansung memberikan dampak penghargaan dan pengakuan karyawan oleh manajemen menjadi baik, sehingga berdampak kepada insentif karyawan semakin meningkat (Fandi \& Diana, 2004).

Penelitian ini sejalan dengan penelitian yang dilakukan oleh Eko Afriyanto (2010) tentang Pengaruh Penerapan Total Quality Management Terhadap Perilaku Produktif Karyawan dan Kinerja Karyawan pada PT "X" di Pasuruan dimana TQM dengan mengambil fokus pada pelanggan dan perbaikan secara berkesinambungan sebagai 
variabel moderating, berpengaruh positif dan signifikan terhadap perilaku produktif karyawan dan kinerja karyawan. Perbedaanya dengan penelitian ini adalah fokus pada pelanggan dan perbaikan secara berkesinambungan merupakan variabel lansung. Adapun variabel yang menjadi tambahannya adalah keterlibatan dan pemberdayaan karyawan yang tidak diteliti oleh peneliti sebelumnya.

\section{b. Penerapan total quality management yang meliputi fokus pada pelanggan, secara parsial tidak berpengaruh terhadap kinerja karyawan pada PT. PLN cabang}

\section{Gorontalo.}

Berdasarkan hasil pengolahan data yang telah dilakukan, penerapan TQM yang meliputi fokus pada pelanggan hanya memberikan konstribusi sebesar 3,8\% tehadap kinerja karyawan sehingga ditolak dan menghasilkan keputusan tidak memberikan pengaruh. Hal ini dimungkinkan mengingat kondisi PLN di wilayah gorontalo hingga saat ini belum stabil, banyaknya complain setiap hari sangat mempengaruhi kinerja dan dianggap karyawan kurang fokus memberikan pelayanan kepada pelanggan sehingga tingkat kepuasan menjadi rendah.

Menurut (Whitely dalam Davis, 2004), karakteristik perusahaan yang sukses dalam membentuk fokus pada pelanggan adalah a). visi, komitmen dan suasana, b). penjajaran dengan pelanggan, memanfaatkan informasi dari pelanggan yakni karyawan memahami bagaimana pelanggan menentukan kualitas dan memahami kebutuhan dan harapan pelanggan.c). mendekati para pelanggan, d). kemampuan, kesanggupan dan pemberdayaan karyawan.

Penelitian ini tidak sejalan dengan penelitian yang dilakukan oleh Eko Afriyanto (2010) dimana fokus pada pelanggan yang merupakan variabel moderating $75 \%$ berpengaruh terhadap kinerja karyawan mengingat obyek penelitian yang dilakukan pada perusahaan $\mathrm{X}$ (perusahaan dagang) memberikan responsif yang tinggi.

c. Penerapan total quality management yang meliputi perbaikan proses berkesinambungan, secara parsial berpengaruh positif dan signifikan terhadap kinerja karyawan pada PT. PLN Cabang Gorontalo 
Berdasarkan hasil olahan data, kosntrbusi yang diberikan atas pengaruh total quality management yang meliputi perbaikan proses berkesinambungan terhadap kinerja karyawan sebesar 39,9\%. dengan probabilitas 0,005. Hasil tersebut mengindikasikan bahwa perbaikan yang berproses secara berkesinambungan menjadi motivasi karyawan dalam menyonsong perubahan dan persaingan yang semakin ketat. Perbaikan tersebut meliputi :

1. Identifikasi dan prioritas tindakan perbaikan yakni perbaikan potensi terhadap pelanggan demi tercapainya tujuan organisasi

2. Metode sistimatis untuk perbaikan dimana timlah yang memerlukan petunjuk bagaimana melaksanakan perbaikan tersebut.

3. Revew terhadap perbaikan, revew terhadap proses memungkinkan anggota tim untuk mengenali pekerjaannya dan mendukung peran manajer sebagai guru.

4. Pembelajaran sistem yang dirancang untuk meningkatkan efisiensi dan tingkat pembelajaran dengan metode ilmiah.

PT. PLN sangat tanggap dengan hal-hal demikian karena tergolong perusahaan Negara yang mengharuskan tanggap terhadap perubahan dan perkembangan yang terjadi dari masa ke masa.

\section{d. Penerapan total quality management yang meliputi keterlibatan dan pemberdayaan karyawan secara parsial berpengaruh positif dan signifikan terhadap kinerja karyawan pada PT. PLN Cabang Gorontalo}

Dari hasil pengolahan data yang telah dilakukan, 46,6\% variabel keterlibatan dan pemberdayaan karyawan memberikan konstribusi terhadap kinerja karyawan. Nilai tersebut dominan dari ketiga variabel yang diteliti, hal ini dapat terjadi karena berdasarkan kondisi dilapangan, memperlihatkan bahwa keingingan pimpinan/manajer memberikan tanggungjawab kepada karyawan dilakukan seluas-luasnya, adanya pelatihan karyawan mengenai bagaimana cara untuk melakukan delegasi dan menerima tanggungjawab, komunikasi dan umpan balik yang diberikan oleh pimpinan/manajer kepada karyawan, adanya penghargaan dan pengakuan sebagai hasil dari evaluasi sebagai tanda penghargaan terhadap konstribusi mereka kepada perusahaan. 
Penelitian ini sejalan dengan penelitian yang dilakukan oleh Putri Restu Mellisa (2009) yang mengukur. Produktivitas Kerja dan kinerja karyawan dari sisi Kemauan Kerja, Kemampuan Kerja, Hubungan Kerja dan Lingkungan Kerja.

\section{F. Kesimpulan}

Dari hasil penelitian dan pembahasan pada bab sebelumnya maka dapat ditarik kesimpulan sebagai berikut :

1. Penerapan Total Quality Management (X) yang meliputi : Fokus pada Pelanggan (X1), Perbaikan proses berkesinambungan (X2) dan Keterlibatan dan Pemberdayaan Karyawan (X3) secara simultan berpengaruh positif dan signifikan terhadap Kinerja Karyawan pada PT. PLN Cabang Gorontalo. Sebesar 67,4\%. , dan selebihan 32,6\% dipengaruhi oleh variabel lain yang belum diteliti, misalnya kesatuan tujuan, kerjasama tim, obsesi yang tinggi terhadap kualitas, pendekatan ilmiah dalam pengambilan keputusan dan pemecahan masalah

2. Penerapan total quality management yang meliputi :

a. Fokus pada pelanggan, secara parsial tidak berpengaruh terhadap kinerja karyawan pada PT. PLN cabang Gorontalo. Pengaruh tersebut hanya berkisar 3,8\% , probabilitas dibawah nilai 0,05 sehingga menghasilkan keputusan ditolak.

b. Perbaikan proses berkesinambungan, secara parsial berpengaruh positif dan signifikan terhadap kinerja karyawan pada PT. PLN Cabang Gorontalo, sebesar $39,9 \%$

c. Keterlibatan dan pemberdayaan karyawan secara parsial berpengaruh positif dan signifikan terhadap kinerja karyawan pada PT. PLN Cabang Gorontalo, sebesar $46,6 \%$

\section{Daftar Pustaka}

Hoyle, D. 2007. Quality Management Essentials. Oxford: Elsevier Limited.

Laksmi Wiro Sita .2005. Pengaruh Teknik Total Quality Management Terhadap Kinerja Manajerial Dengan Sistem Pengukuran Kinerja Dan Sistem Penghargaan Serta Perilaku Manajer Sebagai Variabel Moderating. Skripsi.

Nawawi Hadari. 2006. Evaluasi dan Manajemen Kinerja di Lingkungan Perusahaan dan Industri.Penerbit Gajah Mada University Press. Yogyakarta. 
Notoatmodjo Soekidjo. 2003. Pengembangan Sumber Daya Manusia. Penerbit Rineka Cipta. Jakarta

Nurhayati Dina. 2008. Pengaruh Gaya Kepemimpinan Dan Iklim KerjaTerhadap Kinerja Karyawan Perusahaan Kerajinan AKP CRAFT Bantul.

Prawironegoro Darsono, Ari Purwanti. 2009. Akuntansi Manajemen Edisi 3. Penerbit Mitra Wacana Media. Jakarta

Prawirosentono Suyadi. 2008. Manajemen Sumber Daya Manusia "Kebijakan Kinerja Karyawan”. Penerbit BPFE. Yogyakarta.

Randall S. Schuler, Susan E. Jackson. 1999. Manajemen Sumber Daya Manusia "Menghadapi Abad ke-21". Penerbit Erlangga. Jakarta

Sugiyono. 2011. Metode Penelitian Kuantitatif, Kualitatif, dan R\&D. Penerbit CV. Afabeta. Bandung.

S.P. Hasibuan. 2006. Manajemen Sumber Daya Manusia. Penerbit Bumi Aksara. .Jakarta.

Soemadji Nitisemito Alex. 2001. Manajemen Personalia. Penerbit Ghalia Indonesia.Jakarta.

Sallis, E. 2002. Total Quality Management in Education. Penerbit Kogan Page Ltd. London.

Supriyanto, A. 1999. Total Quality Management di Bidang Pendidikan. Malang: Jurusan Administrasi Pendidikan Fakultas Ilmu Pendidikan Universitas Negeri Malang.

Timpe A.Dale. 1999. Seri Ilmu dan Seni Manajemen Bisnis Kinerja. Gramedia Asri Media .Jakarta

Tjiptono F, dkk. 2003. Total Quality Management (TQM). Penerbit Andi. .Yogyakarta Yogyakarta. 2004. Perspektif Manajemen dan Pemasaran Kontemporer. Penerbit Andi.

Tjiptono Fandy \& Diana. 2010. Total Quality Management edisi revisi. Penerbit Andi, Yogyakarta

Umar. H. 2006. Metode Riset Perilaku Konsumen Jasa. Penerbit Ghalia Indonesia, Jakarta.

Wirawan. 2009. Evaluasi Kinerja Sumber Daya Manusia “Teori, Aplikasi dan Penelitian”. Penerbit Salemba Empat. Jakarta.

http://gorontalo.bps.go.id/files/publikasi/flipping/pub_109_2013-09

25/files/search/searchtext.xml 